\title{
Reasons and Countermeasures of Accounting Information Distortion of Listed Companies in Our Country
}

\author{
Shujun Sheng \\ Shanghai Normal University Tianhua College \\ Shanghai, 200233, China
}

\begin{abstract}
Accounting information disclosed by listed companies is an important basis for investors, creditors, the public and internal managers to make investment decisions on financial status and operating results and improve operation and management. Its authenticity is the most basic principle to measure the quality of accounting information. At present, there is a widespread phenomenon of accounting information distortion in listed companies, which poses a serious threat to market economic order and standard management on enterprises. Accounting information distortion of listed companies will inevitably lead to decision-making errors, reduce the quality and use efficiency of information and bring significant economic losses to stakeholders, thus affecting the credibility and vitality of accounting professionals. Therefore, this paper reflects on the causes of accounting information distortion in listed companies and analyzes and provides effective countermeasures from four aspects: the governance mechanism of listed company, punishment on fraud, accounting management system and the quality of accounting personnel.
\end{abstract}

Keywords-listed company, accounting information distortion, countermeasure

\section{THE MEANING OF ACCOUNTING INFORMATION DISTORTION}

Accounting information distortion refers to the accounting information that does not meet the requirements of accounting standards, that is, false financial information, which cannot objectively reflect the financial status and business results of enterprises, and bring adverse effects to the decision makers for relevant decisions.

The forms of accounting information distortion include false accounting information and accounting information fraud. False accounting information is caused by the negligence of accounting practitioners themselves, for example, errors in the copying of original vouchers and the wrong use of accounting policies, so that the accounting information could not accurately and objectively reflect the financial status and operating results of enterprises. False accounting information is not the subjective intention of accounting personnel, but a kind of dereliction, which mainly results from their misjudgment, inexperience and limited ability to deal with accounting affairs and other reasons. 1
Accounting information fraud is that financial personnel make false accounting information through fraud and other means for their own interests. It mainly includes:

(1) Information distortion provided by accounting vouchers. The original vouchers of some units are incomplete, making a few illegal incomes and expenditure became legitimate one. At the same time, vouchers are forged or arbitrarily altered and transactions are concealed or deleted, then accounting vouchers cannot truly reflect business economic activities. As the accounting information provided is false, the final accounting statement data is necessarily false.

(2) Information distortion generated by accounting books The data of accounting books come from vouchers. Since accounting vouchers are false, accounting books are inevitable distorted. Accounting fraud is that enterprises cover up the real accounting information through the alteration of accounts and manipulation of account in the process of bookkeeping and closing of accounts. For example, enterprises do not set up accounting subjects in strict accordance with the provisions of the Ministry of Finance. In addition, distortion of income and cost can also lead to distortions in the information generated by account books. Among them, transfer income and support income is the main forms of income distortion. Cost with more or less items is the main form of cost distortion.

(3) The information provided by financial accounting reports is distorted. In drawing up accounting statements, the number in statements is adjusted on purpose according to the needs of one's own interests. And the accounting statements with different purposes are submitted to different departments. As a result, users of the statements cannot understand the true financial status and operating results of enterprises. For example, in order to gain the trust of the bank for more loans, some people adjust the profit of enterprises arbitrarily in the preparation of the income statement and fabricate accounting statements with larger profits.

\section{THE REASONS FOR THE ACCOUNTING INFORMATION} DISTORTION

\section{A. Defects in the governance structure of listed companies}

The listed company has set up shareholders' meeting, the board of directors, the board of supervisors and the managers, which coordinate and balance each other to form the 
governance structure of the listed company. However, at present, the common problem in the governance structure of listed companies in China is "the dominance of one shareholder", which leads to the weakening of shareholders' restraint on business operators. Shareholders can use their large number of shares to recommend themselves to the board. To be a director of the company, it must be approved in shareholders' meeting, and shareholders can use their larger number of holdings to form a majority opinion in the general meeting of shareholders, thus entering the board of directors.

At present, due to the unreasonable structure of the board of directors in listed companies in China and the excessive concentration of stock rights, the information is asymmetric among the major shareholders, medium and small shareholders in listed companies in China. Thus, when serious conflicts of interest occurs between shareholders and other medium and small shareholders, shareholders can take advantage of the asymmetric information to realize their own interests at the expense of other medium and small shareholders' interests and make false accounting information for external disclosure, thus harming the interests of other medium and small shareholders.
On the other hand, at present, some members of the board of directors in listed companies are also senior managers of companies. As a result, the board of directors inevitably loses its role as supervising managers, which directly affects the quality of accounting information disclosure.

\section{B. Insufficient punishment}

Although at present, some laws and regulations of our country have punishment provisions for making false accounting information. However, due to a variety of reasons, laws are not abided by or fully enforced. The punishment for violation of accounting laws and regulations is not enough, which cannot play the role of punishment.

According to WIND statistics, 42 times punishment were imposed on a total of 39 A-share listed companies by China Securities Regulatory Commission and Shanghai and Shenzhen stock exchanges for various violations during the period from January 1, 2010 to March 8, 2011. Although there are a lot of penalties, it can be seen from TABLE I that the punishment on listed companies for violations is generally between 300,000 and 400,000 Yuan.

TABLE I. PENALTY FOR VIOLATION IN LISTED COMPANIES (STATISTICS PERIOD: JANUARY 1, 2010-MARCH EIGHT, 2011)

\begin{tabular}{|c|c|c|c|c|c|}
\hline Series & Name & Date of publicity & Types of violation & $\begin{array}{l}\text { Types of } \\
\text { treatment }\end{array}$ & $\begin{array}{c}\text { Fine(ten } \\
\text { thousand } \\
\text { Yuan) }\end{array}$ \\
\hline 1 & Beihai port & $2011-2-22$ & $\begin{array}{c}\text { False information } \\
\text { disclosure or serious } \\
\text { misleading statement }\end{array}$ & $\begin{array}{c}\text { Public } \\
\text { punishment }\end{array}$ & 30 \\
\hline 2 & ST Jiantong & 2011-1-12 & $\begin{array}{l}\text { False information } \\
\text { disclosure }\end{array}$ & $\begin{array}{c}\text { Public } \\
\text { punishment }\end{array}$ & 30 \\
\hline 3 & $\begin{array}{c}\text { Tianmu } \\
\text { Pharmacy }\end{array}$ & 2011-1-29 & $\begin{array}{c}\text { Fail to disclose major } \\
\text { issues of companies } \\
\text { timely }\end{array}$ & $\begin{array}{c}\text { Public } \\
\text { punishment }\end{array}$ & 40 \\
\hline 4 & $\begin{array}{c}\text { Dongyuan } \\
\text { electric appliance }\end{array}$ & 2011-1-13 & $\begin{array}{l}\text { Fail to fulfill other } \\
\text { obligation }\end{array}$ & $\begin{array}{c}\text { Public } \\
\text { criticism }\end{array}$ & 0 \\
\hline 5 & ST Jinxiang & $2010-12-21$ & $\begin{array}{c}\text { Fail to disclose major } \\
\text { issues of companies } \\
\text { time }\end{array}$ & $\begin{array}{c}\text { Public } \\
\text { punishment }\end{array}$ & 30 \\
\hline
\end{tabular}

It should be noted that these punished listed companies may have earned more money than the fine amount by virtue of these false accounting information.

At the same time, China now has mainly adopted the measures of ordering for correction, internal notice of criticism, public condemnation, warning and fine for the listed companies' illegal information disclosure. And the internal notice of criticism and public condemnation are the main punishment, of which the internal notice of criticism accounts for $60 \%$ of the total punishment and public condemnation accounts for $20 \%$.

The effect of the above-mentioned punishment can also be seen from the data of the companies that are punished for violating rules again. As can be seen from TABLE II, the effect of internal criticism is very limited. Many companies will continue to disclose false financial information after being punished for the first time. Among them, $20 \%$ to $40 \%$ of punished companies will be punished again after being punished for the violation of information disclosure. On average, a third of companies that are penalized will violate rules again and be penalized again. Such a high rate is of great concern and fully demonstrates that this punishment does not exert its real deterrent.

Statistics score of violation again by different types of punishment is shown in TABLE II 
TABLE II. STATISTIC SCORE OF VIOLATION AGAIN BY DIFFERENT TYPES OF PUNISHMENT ${ }^{1}$

\begin{tabular}{|l|c|c|c|c|c|c|}
\hline \multicolumn{1}{|c|}{ The First Punishment } & \multicolumn{5}{c|}{ The Second Punishment } \\
\hline Types & Times & $\begin{array}{c}\text { Internal } \\
\text { Criticism }\end{array}$ & Warning & $\begin{array}{c}\text { Public } \\
\text { Condemnatio } \\
\mathrm{n}\end{array}$ & $\begin{array}{c}\text { Order For } \\
\text { Correction }\end{array}$ & Proportion(\%) \\
\hline $\begin{array}{l}\text { Internal } \\
\text { Criticism }\end{array}$ & 135 & 11 & 7 & 9 & 0 & $27(20 \%)$ \\
\hline Warning & 29 & & 1 & 1 & & $1(7.6 \%)$ \\
\hline $\begin{array}{l}\text { Public } \\
\text { Condemnation }\end{array}$ & 50 & 1 & 1 & 4 & 0 & $6(12 \%)$ \\
\hline $\begin{array}{l}\text { Order For } \\
\text { Correction }\end{array}$ & 4 & 1 & 1 & & 0 & $2(50 \%)$ \\
\hline Proportion(\%) & 218 & 13 & 9 & 14 & 0 & $36(16.5 \%)$ \\
\hline
\end{tabular}

It can be seen that although the existing laws and regulations of China have made relevant provisions on the distortion of accounting information disclosure, many enterprises still choose to disclose false accounting information for their own interests due to weak punishment.

\section{Imperfect management system of accounting personnel}

The current accounting personnel in China are mainly managed by the employers themselves and Ministry of Finance shall examine and verify their professional qualifications. Their salary, bonus and promotion are controlled by the leaders of companies. Person in charge in some companies use their rights to instigate the accounting personnel to make false information, while the accounting personnel have to obey leaders' arrangement for their own interests and process accounting in violation of accounting standards according to leaders' opinion, thereby accounting personnel cannot play a role of supervision or even take the initiative to make false, thus leading to the distortion of accounting information of listed companies.

\section{Low quality of some accountants with weak accounting foundation}

All the accounting information disclosed by listed companies are collected, sorted out and accounted by accountants of enterprises. Therefore, accountants need to judge or deduce some uncertain factors in objective economic activities. Due to their different levels of experience and knowledge, different understanding on new policies and regulations system and the lack of proper professional judgment ability in some economic activities, especially the complex economic activity, it is difficult for them to deal with more complex business accounting, thus the measurement of the accounting data do not tally with the actual situation and real accounting information cannot be provided.

The false information disclosed by enterprises is undoubtedly modified by accounting personnel in enterprises. Therefore, the key for listed companies to account accounting information lies in the practical operation level of accountants. For example, in order to exaggerate the performance and achieve the purpose of rights offerings, Yinchuan Guangxia Industrial Co., LTD. released the net profit of 546 million
Yuan to the society through the disclosure of false accounting information, forging the purchase and sale contract, falsely making out VAT and other means, which make its share prices artificially high, thus earning huge profits, harming the interests of small and medium-sized shareholders and directly causing the loss of 6.86 billion Yuan for investors. For the disclosure of the false accounting information, there is no doubt that they are produced through the operation of company's accounting personnel. At present, the professional ethics of accounting personnel in China, especially those in listed companies, is not optimistic. They have lost their work independence, ignored their professional competence, worked in a non-standard manner and had a poor sense of confidentiality, weak sense of quality and serious fraud, which directly leads to incorrect disclosure of accounting information in enterprises.

\section{COUNTERMEASURES FOR DISTORTION OF ACCOUNTING INFORMATION}

\section{A. It should improve governance mechanism of listed companies}

At present, the governance mechanism of listed companies in China is not perfect. "The dominance of one shareholder" is the most common problem in the governance structure of listed companies in China. Therefore, we should deal with and improve this problem. Such a phenomenon will make it difficult for the medium and small shareholders to unite to effectively restrain the operators of enterprises. Therefore, in listed companies, it should appropriately reduce the number of shares of major shareholders and introduce other investors, so that more medium and small shareholders can play a role in the board of directors. Moderate concentration of equity is conducive to the improvement and optimization of corporate governance structure to a certain extent.

At the same time, it is common for directors of listed companies in China to serve as managers. With the lack of independent director system, the supervisory role of independent director in information disclosure cannot be played out. Although China Securities Regulatory Commission has made specific provisions on the number of independent directors of listed companies, it is difficult for the independent 
board of directors of listed companies to play its role due to the lack of explanation on the selection, appointment and responsibilities of independent directors.

At present, the independent directors of listed companies are generally decided by major shareholders. And the small and medium-sized shareholders have no real role in this regard. When the listed companies disclose accounting information, the independent directors seldom express their opinions.

Therefore, in order for the independent directors of listed companies to play their supervisory role and safeguard the rights and interests of minority shareholders, we must first regulate the current mechanism of the selection and appointment of independent directors in China, so that minority shareholders have the right to express their suggestions and opinions on the board of directors. Second, the selection of independent directors should be strictly conducted. When selecting independent directors, those with high sense of social responsibility and competence should be selected to serve as independent directors. Third, the rights and responsibilities of independent directors should be standardized so that independent directors can express their independent opinions when accounting information is disclosed.

Only by gradually reducing the shareholding ratio of major shareholders of listed companies and constantly improving the system of independent director in listed companies can independent directors play an important supervisory role when enterprises disclose false accounting information and strive for the interests of the majority of investors.

\section{B. It should intensify legal punishment}

First of all, it should intensify the punishment of illegal behavior from the legal norms. From the TABLE II, it can be seen that, due to the insufficient punishment for corporate intentional counterfeiters, $20 \%$ of enterprises still choose to disclose false accounting information for the second time after receiving the first punishment. The reason is that the first punishment is not strong enough which makes these companies still dare to take risks to make false accounting information. Therefore, it should strengthen the punishment on false accounting information to make the cost of false information produced by the counterfeiters far exceed their income, so as to reduce the occurrence of false accounting information.

At present, the punishment for false accounting information disclosure in our country is mainly administrative punishment and its main means are warning and economic punishment. It is necessary to impose administrative punishment on enterprises providing false accounting information, which has a certain disciplinary effect and can to a certain extent restrain the behaviors of managers in listed companies. The effects of administrative penalties can be seen in TABLE II. Although the situation has been improved, the role of administrative punishment is very limited. It is difficult to form a sufficient deterrent to the parties. Therefore, the author believes that it should combine administrative punishment and criminal punishment to continuously increase the punishment on false accounting information disclosure so as to systematically curb its occurrence.
The Securities Law in China stipulates that the administrative penalty for listed companies and their administrative authorities ranges from 300,000 Yuan to 600,000 Yuan. Take Yinchuan Guangxia company for example, the penalty is only 600,000 Yuan, but this is the maximum penalty. However, in order to exaggerate performance and increase capital and rights offering, Yinchuan Guangxia released false net profit of 546 million Yuan to the society, directly causing a loss of 6.86 billion Yuan for investors. Only 600,000 Yuan of fines is really insignificant when compared with the illegal benefits obtained by Yinchuan Guangxia.

Therefore, it is necessary to intensify the punishment on companies and the direct person in the disclosure of false information in the law and the amount of punishment should be much higher than the profit obtained so as to prevent the listed company from disclosing false information. The author believes that we can draw lessons from the legal provisions of some developed countries. For example, French criminal law stipulates that "if the head of a company intentionally destroys or conceals accounting documents, he/she will be sentenced to three years' imprisonment and a fine of 300,000 francs; if a document is forged or misused, it will be fined 1.5 million francs and forced to declare bankruptcy." 4 The introduction of such severe legal sanctions will be conducive to intensify the adjudication for fraud cases and to play a role of warning to discredit or even ruin the counterfeiters.

\section{It should improve accounting management system.}

The current accounting system is prone to cause accountants to attach themselves to enterprises. Financial personnel cannot effectively carry out their supervision role in the economic illegal phenomena in companies. To maintain the objectivity and authenticity of accounting information, it is necessary to strengthen financial supervision and control, and improve the current management system of accounting personnel.

First, it should carry out accountant appointment system. Accounting appointment system refers to the system of sending accounting personnel to enterprises directly by government accounting departments. The employment, job transfer, appraisal of professional title, salary and promotion, bonus and related welfare of appointed accountants are separated from companies, which shall be the responsibility of the delegated authority and not be controlled by the person in charge of companies, thus ensuring the independence of the accounting personnel and avoiding providing false accounting information. By doing so, it can avoid employers to make fraud and ensure the status and treatment of accounting personnel and their right of supervision, thus effectively curbing the occurrence of illegal phenomenon.

Furthermore, it should optimize the structure of accounting personnel, strengthen professional management and improve accounting system. Before their work, it must examine their moral and professional quality to ensure their comprehensive quality from very beginning. The accounting personnel in the whole country shall be registered, archives management system for moral behavior shall be established, and corresponding reward and punishment measures shall be taken. It should 
award those accountants who adhere to principles and professional ethics. For those accountants who violate regulations seriously, their professional qualifications will be canceled and given penalties and the evaluation results will be recorded in their personal integrity file, so as to enhance their awareness of integrity, reduce the occurrence of accounting information distortion and mobilize the power of public opinion to fight against fraud through the news media,.

\section{It should strengthen the building of accounting team}

Accountants are the direct providers of accounting information in enterprises. Therefore, the quality of accounting information is determined by their professional quality and professional ethics. It should, first of all, strengthen continuing education and training to improve their professional quality. It should conduct continuing education and training in accordance with the work requirements of accountants at different levels and encourage them to learn various business knowledge and financial laws and regulations and accumulate experience in practice.

It should emphasize the cultivation of professional ethics while improving professional quality. It should make accounting personnel deeply aware of the importance of accounting integrity for the survival of enterprises and personal career development through extensive publicity and education. They should always demand themselves with the ethical standards of integrity and subjectively adhere to do not fake accounts. It should strengthen their legal education; organize them to learn national financial and economic principles and policies and comprehensively master relevant knowledge and regulation with which they can be able to discipline themselves. Additionally, they should enhance the ability of self-restraint, gradually establish the correct professional view and maintain their good social image. Accounting personnel are in control of companies' financial situation, so the improvement on their professional ability and moral cultivation can effectively enhance the authenticity and reliability of enterprises' disclosure of accounting information.

\section{REFERENCES}

[1] Zhang Zhaoxia, Research on the Relationship between Accounting Information Distortion and Enterprises' Debt and Financing--Based on Internal Adjustment Effect[J]. Communication of Finance and Accounting, 2018(11) (In Chinese)

[2] Xu Jun. On Accounting Information Distortion in Listed Companies[J]. Communication of Finance and Accounting, 2018(9). (In Chinese)

[3] Yu Yuying, Yang Zhan, Fu Fangxing. Reflection on Improvement of Legal Liability of Accounting Information Distortion in Our Country-From the Perspective of Institutional Economics[J]. Communication of Finance and Accounting, 2019(4) (In Chinese)

[4] Li Juying. On Problems and Countermeasures of the Building of Accountants' Professional Ethics[J]. Journal of Shanxi University of Finance and Economics, 2019 (4). (In Chinese)

[5] Xing Enquan, Song Rui, Sui Rui, Cao Leina. On Prevention of Accounting Information Distortion of Listed Companies from Perspective of Blockchain[J]. Finance and Accounting, 2019(1). (In Chinese)

[6] Gao Yanhong, et al. On Updating Knowledge Structure of Accountants in Knowledge Economic Era[J]. Economy and Technology Coordinated Information, 2011(3). (In Chinese)

[7] Cen Lei, Zhu Wenli. Research on Government Function in Accounting Information Disclosure in Listed Companies[J]. Communication of Finance and Accounting, 2009(6). (In Chinese)

[8] Zhu Weiyi. Interpretation on Cases of Securities Law. China Legal Publishing House, July, 2002.(In Chinese) 